\title{
Ecological Microclimate Influence on Grapevine Phomopsis viticola Attack Frequency in Aiud- Ciumbrud Vineyards
}

\author{
Sergiu SAVU ${ }^{1}$, Liliana Lucia TOMOIAGA ${ }^{2}$ and Veronica Sanda CHEDEA ${ }^{2 *}$ \\ ${ }^{1}$ Pivnita Savu, Ciumbrud, Romania \\ ${ }^{2}$ Research Station for Viticulture and Enology Blaj (SCDVV Blaj), 2 Gh Baritiu St, Blaj, Romania \\ *corresponding author: chedeaveronica@yahoo.com
}

BulletinUASVM Horticulture 77(2) / 2020

Print ISSN 1843-5254, Electronic ISSN 1843-5394

DOI:10.15835/buasvmcn-hort: 2020.0026

\begin{abstract}
Phomopsis viticola (Sacc.) Sacc. (syn. Cryptosporella viticola Shear, Diaporthe viticola Nitschke, Diplodia viticola Desm, Fusicoccum viticolum Reddick, Phoma flaccida Viala \& Ravaz, Phoma viticola Sacc.), is the causal agent of the grapevine disease named 'Phomopsis cane' and 'Leaf spot' in the U.S.A. or 'Excoriose' in Europe. This study aims to evaluate the influence of the microclimate on Phomopsis viticola attack in Aiud-Ciumbrud vineyards. The observations were done on four plots in Aiud-Ciumbrud vineyards in the period March-August 2020. Up to the end of August 2020, ten treatments with contact and systemic products based on metiram and sulphour were done together with the other standard agro-technological operations. In the ecological conditions of spring-summer 2020, with higher temperature than the average in January, February, March and June, more rain than the average in February, March and June and less rain in January, April and May, we found frequency of the excoriosis in the range of $4 \%-12 \%$ at the beginning of the season. After the fungicide treatments, the attack frequency decreased up to $0 \%-7 \%$. In the present research work, we show that in Aiud-Ciumbrud vineyards Phomopsis viticola attack was present and influenced by the microclimate conditions and also it was reduced by the fungicide treatments.
\end{abstract}

Keywords: Aiud-Ciumbrud vineyards, attack frequency, microclimate, Phomopsis viticola

\section{Introduction}

Phomopsis viticola (Sacc.) Sacc. (syn. Cryptosporella viticola Shear, Diaporthe viticola Nitschke, Diplodia viticola Desm, Fusicoccum viticolum Reddick, Phoma flaccida Viala \& Ravaz, Phoma viticola Sacc.) (https://www.cabi.org/ isc/datasheet/40489) is the causal agent of the grapevine disease named 'Phomopsis cane' and 'Leaf spot' in the U.S.A. or 'Excoriose' in Europe. Because the preferred scientific name is Phomopsis viticola (Sacc.) Sacc., we will use it further (https://www.cabi.org/isc/datasheet/40489). The pathogen has been showed for the first time in studies conducted during the first decade of the 1900s in North America by plant pathologist Donald Reddick at the Cornell University State Agricultural Experiment Station in Geneva, New York. The fungus, was associated with symptoms resembling what we know today as Phomopsis cane and leaf spot and Phomopsis dieback characterised by grapevine cankers and dieback (Urbez-Torres et al., 2013). The most characteristic symptoms attributed to Phomopsis dieback, one of the grapevine trunk diseases, are perennial cankers in the framework of the vine and lack of budbreak from infected spurs (Urbez-Torres et al., 2013; Gramaje et al., 2018). Symptoms of Phomopsis dieback were shown to be particularly 
high in vineyards severly affected by Phomopsis cane and leaf spot (Baumgartner et al., 2013; Urbez-Torres et al., 2013). Presently, seven species in the genera Diaporthe have been shown to be pathogenic on grapevine wood (Baumgartner et al., 2013; Dissanayake et al., 2015; Urbez-Torres et al., 2013; Gramaje et al., 2018). Among them, Phomopsis dieback is primarily caused by the most virulent $P$. viticola, which has long been known as the causal agent of the Phomopsis cane (Phillips, 2000; Urbez-Torres et al., 2013; Gramaje et al., 2018).

It has been shown that spore release, and hence high risk infection periods, vary throughout the growing season depending on the fungal pathogen and geographical location, but primarily overlap with dormant pruning seasons ascospores and conidia are released under favorable environmental conditions, which are primarily associated with rain events and/or high relative humidity along with temperatures above freezing, which also favor spore germination (Úrbez-Torres et al., 2010, van Niekerk et al., 2010; Gramaje et al., 2018). Spores are then spread from pycnidia or perithecia by rain droplets, wind, or arthropods until they land on susceptible pruning wounds to germinate and start colonizing new xylem vessels and pith parenchyma cells (Mostert et al., 2006; Moyo et al., 2014; Gramaje et al., 2018).
In Romania, Excoriose was found in vineyards in Valea Călugarească Odobeşti, CoreteştiVrancea, Pietroasele and Drăgășani (Oprea and Podosu, 2008). Generally, in Transylvania the grapevine trunk diseases affect up to $5 \%$ of the vineyards although there are also vineyards where the incidence of the attack exceeds $15 \%$ (Tomoiaga and Chedea, 2020). Excoriose caused by Phomopsis viticola was also reported for the Tarnave vineyards together with other grapevine trunk diseases (Comsa et al., 2012).

The area of the Ciumbrud hills is appreciated by specialists as one of the oldest and most famous wine-growing areas in Transylvania and in the whole country, in which there are two large vineyards, Târnavelor and Alba Iulia. The village of Ciumbrud, together with its vineyards is part of the Alba Iulia Vineyard, also called the Wine Country. The Ciumbrud POD and table wines are generally white dry and semidry.

In this context, this study aims to evaluate the influence of the microclimate on Phomopsis viticola attack as well as its management with fungicide treatments in Aiud-Ciumbrud vineyards.

\section{Materials and methods}

The observations were done on four plots (Fig. 1) in Aiud-Ciumbrud vineyards in the period March-August 2020.

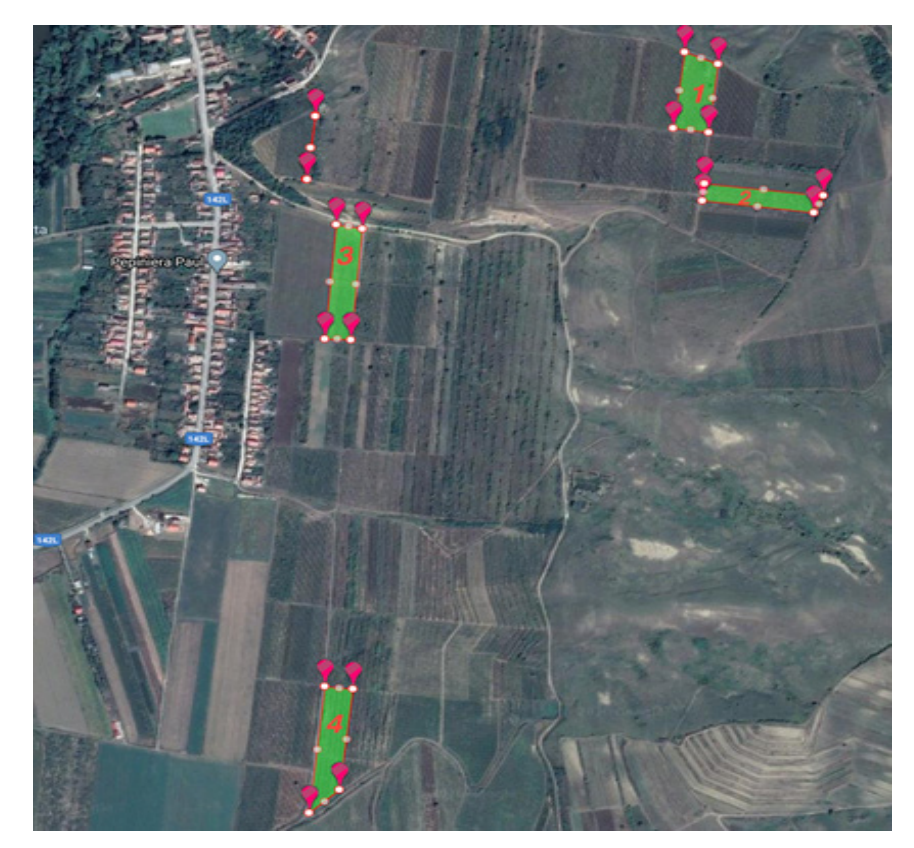

Figure 1. The spatial distribution of the four plots examined for the excoriose frequency in the Aiud-Ciumbrud vineyard 
The information regarding the four plots, surface, altitude, number of examined vines, vine rows orientation, vine age and the embankment are shown in Table 1.
The evaluations of excoriosis symptoms presence on vines were done three times, first in 13.03.2020, second in 27.06.2020 and third in 16.08.2020. The Phomopsis viticola's frequency (F) was calculated using the following formula:

Table. 1. The experimental plots used in this study as well as their surface, altitude, number of vines examined and marked, rows orientation, vine age and embankment

\begin{tabular}{cccccccc}
\hline $\begin{array}{c}\text { Plot } \\
\text { no. }\end{array}$ & Plot name & Surface & $\begin{array}{c}\text { Altitude } \\
(\mathrm{m})\end{array}$ & $\begin{array}{c}\text { No. of vines } \\
\text { examined } \\
\text { and marked }\end{array}$ & $\begin{array}{r}\text { Vine rows } \\
\text { orientation }\end{array}$ & $\begin{array}{r}\text { Vine age } \\
\text { (years) }\end{array}$ & $\begin{array}{c}\text { Embank- } \\
\text { ment }\end{array}$ \\
\hline 1 & 'CHISAUAS'- 'Muresan' & 0.84 & 310 & 3000 & N-S & 41 & No \\
\hline 2 & 'CHISAUAS' -'Tinca' & 0.62 & 315 & 2000 & E-V & 41 & No \\
\hline 3 & RS (Traminer) & 0.30 & 230 & 1000 & N-S & 39 & No \\
\hline 4 & Sancrai - Terase & 0.80 & $230-240$ & 3366 & N-S & 40 & Yes \\
\hline
\end{tabular}

Table. 2. Treatments applied for grapevine fungal diseases and pests in Ciumbrud vineyard for the period March-August 2020

\begin{tabular}{cc}
\hline $\begin{array}{c}\text { Treatment } \\
\text { no. }\end{array}$ & Active substance \\
\hline 1 & 13.03.2020-first Phomopsis viticola frequency evaluation \\
\hline 2 & Copper Sulphate Pentahidrate+ Sulphur $80 \%$ \\
\hline 3 & Copper hydroxide $+50 \%$ Metallic copper \\
Abamectin $18 \mathrm{~g} / \mathrm{l}$ \\
Sulphur $80 \%$
\end{tabular}


(number of vines with symptoms/ total number of examined vines) $\times 100$; applied for all four plots.

Up to the end of August 2020, ten treatments with contact and systemic products based on metiram and sulphour were done together with the other standard agro-technological operations. Treatments were applied with varied products and they are listed in Table 2.

The climatic data for the studied period were collected from the vineyard and also downloaded from https://www.meteoblue.com/ ro. The experimental data were analyzed with the Statview 5.0 program performing one-way analysis of variance (ANOVA), followed by a Fisher protected least significant difference (PSLD) test. The average and SEM (standard error of the mean) were calculated and $P$ values lower than 0.05 were considered significant while $\mathrm{P}$ values between 0.05 and 0.1 were considered as tendencies.

\section{Results and discussions}

Due to its geographical location, in the wide contact area of two large geomorphological units, mountain and plateau, on the well-known depression alley Alba Iulia-Turda, Ciumbrud is supported on the following forms of relief: hill, terrace, meadow and plateau. The mountain range of the Apuseni Mountains, through its protective orientation, creates obstacles in the way of strong, dry and cold winds, calms their action and effects, modify climatic factors, creating microclimates that are particularly useful for the cultivation of grapevine. The hills occupy approximately 40\% of the surface of the out-of-town territory, having a dominant E-V orientation, with slopes reaching values of 8-18 degrees. The eastern slopes are gentler and longer, the western ones fall steeply above the Mureș. Slope orientation is dependent on the southern regions, as it is closer or farther from them.

The geographical location of Ciumbrud frames the locality and the Aiud area in the temperate continental climate, with slight moments of excess due to the general circulation of the atmosphere on one hand and the local peculiarities and the active relief surface on the other. The wide corridor of Mures favors the western circulation through which the wetter air masses reach here. On this predominant influence are superimposed those of the southern and southwestern circulation that bring warmer air masses. Figure 2 presents the climatogram of the studied Ciumbrud area for the period January-July 2020.

As Figure 2 indicates for the period JanuaryJuly 2020 in Ciumbrud vineyard it was an average temperature at soil level of $8.97^{\circ} \mathrm{C}$, in the air of $10.35^{\circ} \mathrm{C}$, the sum of precipitations was $420 \mathrm{~mm}$, there were 105 days of vegetation, 495 cloudy hours, 1395 sunny hours, and an average solar radiation in $24 \mathrm{~h}$ of $127.3 \mathrm{w} / \mathrm{m}^{2}$. The average precipitations and the average temperature is presented together with the multiannual values for the same months. Thus we observed higher temperature than the average in January,

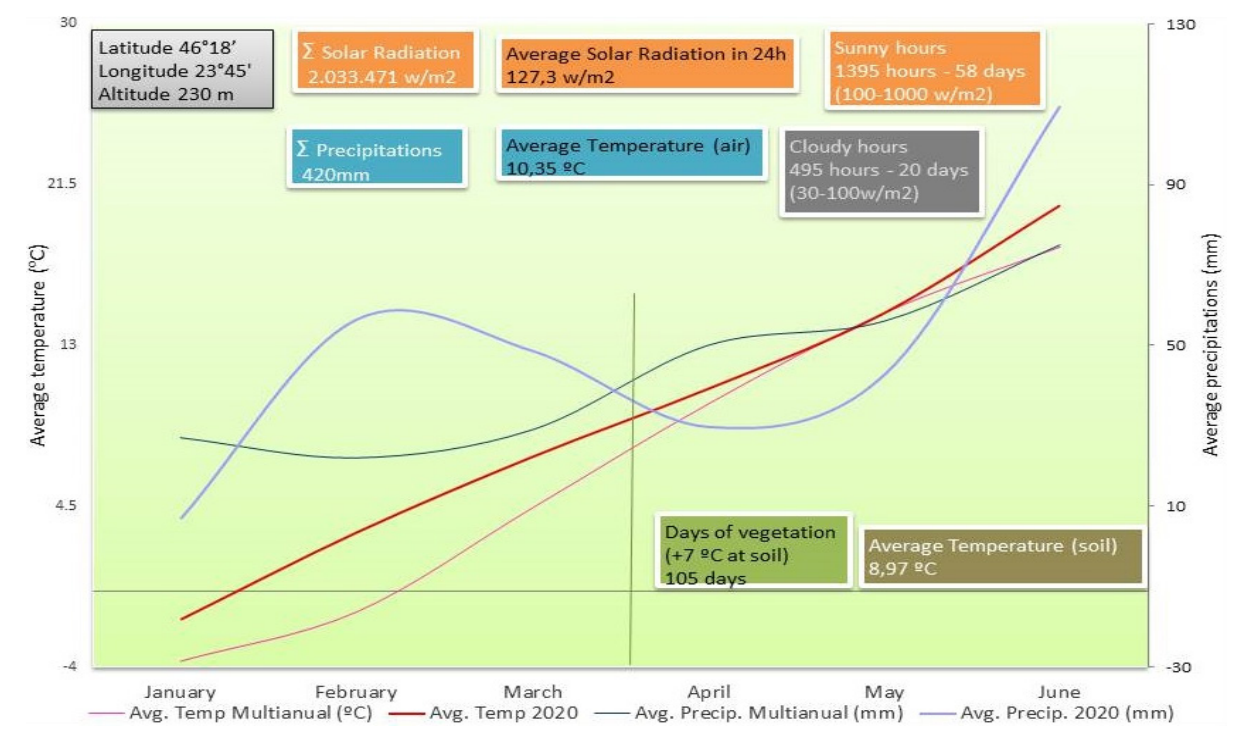

Figure 2. Climatogram of the studied Ciumbrud area for the period January-July 2020 


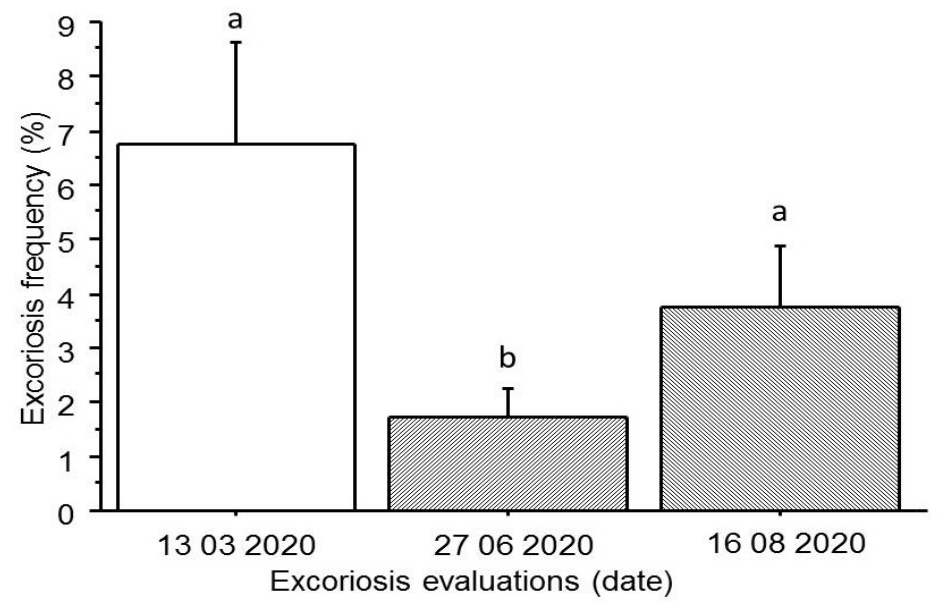

Figure 3. The excoriosis frequency during the studied growing season Different letters between cultivars denote significant differences (ANOVA), followed by a Fisher protected least significant difference test (PSLD) $p<0.05$.

February, March and June, more rain than the average in February, March and June and less rain in January, April and May. An important role in the evolution of excoriosis is played by weather conditions, namely rainfall and temperature (Comsa et al., 2012). Figure 3 shows the dynamics of Phomopsis viticola attack frequency during this period and as it can be seen the highest values are registered in the middle of March, after the cold and humid months of January and February. Due to the fungicid treatments in the March-June period the Phomopsis viticola attack lowered to an average of $1.75 \% \pm 0.8$ as the second evaluation from 27.06.2020 indicates (Fig. 3). The month of June was characterized by heavy rains and this can explain a slight increase in Phomopsis viticola attack observed by August $16^{\text {th }}$ (Fig. 3). For all the period studied the fungicide treatments (Tab. 2) as well as the agrotechnological works were done appropriately.

In the Blaj vineyards in 2010 Phomopsis viticola had a higher intensity and this allowed the authors to establish correlations between disease intensity and weather conditions (Comșa et al., 2012). Although P. viticola occurs wherever grapes are grown (Farr and Rossman, 2012), Phomopsis cane and leaf spot is more severe in grape-growing regions characterized by a humid temperate climate through the growing season (Urbez-Torres et al., 2013). Crop losses up to 30\% have been reported to be caused by Phomopsis cane and leaf spot (Erincik et al., 2001; Pscheidt and Pearson, 1989; Urbez-Torres et al., 2013). P. viticola can infect all green parts of the grapevine, and thus disease symptoms can be observed on leaves as small pale-green to yellow spots with necrotic centers (Urbez-Torres et al., 2013) (Fig. 4). Canes show brown to black necrotic irregularshaped lesions (Fig. 4) and clusters show rachis necrosis and brown, shriveled berries close to harvest (Hewitt and Pearson, 1988; Urbez-Torres et al., 2013).

The first symptoms appear in early spring with the growing season, when bud break is delayed (Comsa et al., 2012) (Fig. 4A). The buds located on the cordons do not start to grow, causing denudation of canes. Black small round or linear, more or less deep lesions appear in the shoots (Fig. 4B). Round spots, up to $1.5 \mathrm{~cm}$ in diameter, blackish brown with a yellow-orange halo emerge on the leaves (Fig. 4C and 4D). After the grapes enter veraison, the berries rot and are covered by fungi fructifications. The infections are favored by cold and wet weather (Comsa et al., 2012).

Oprea and Podosu (2008) indicated that the grapevine growing on the areas with clay compact acid soil, watered in excess and industrially polluted, is more affected by excoriose.

The wind is the climatic element that reflects the influence of the general circulation of the atmosphere, the direction being for our studied area NE-V. In case of Phomopsis viticola, the dispersion of the spores are primarily spread through the air (Gramaje et al., 2018). As our experimental plots are oriented N-S and E-V (Tab. 1) we assumed that the frequency of excoriosis 


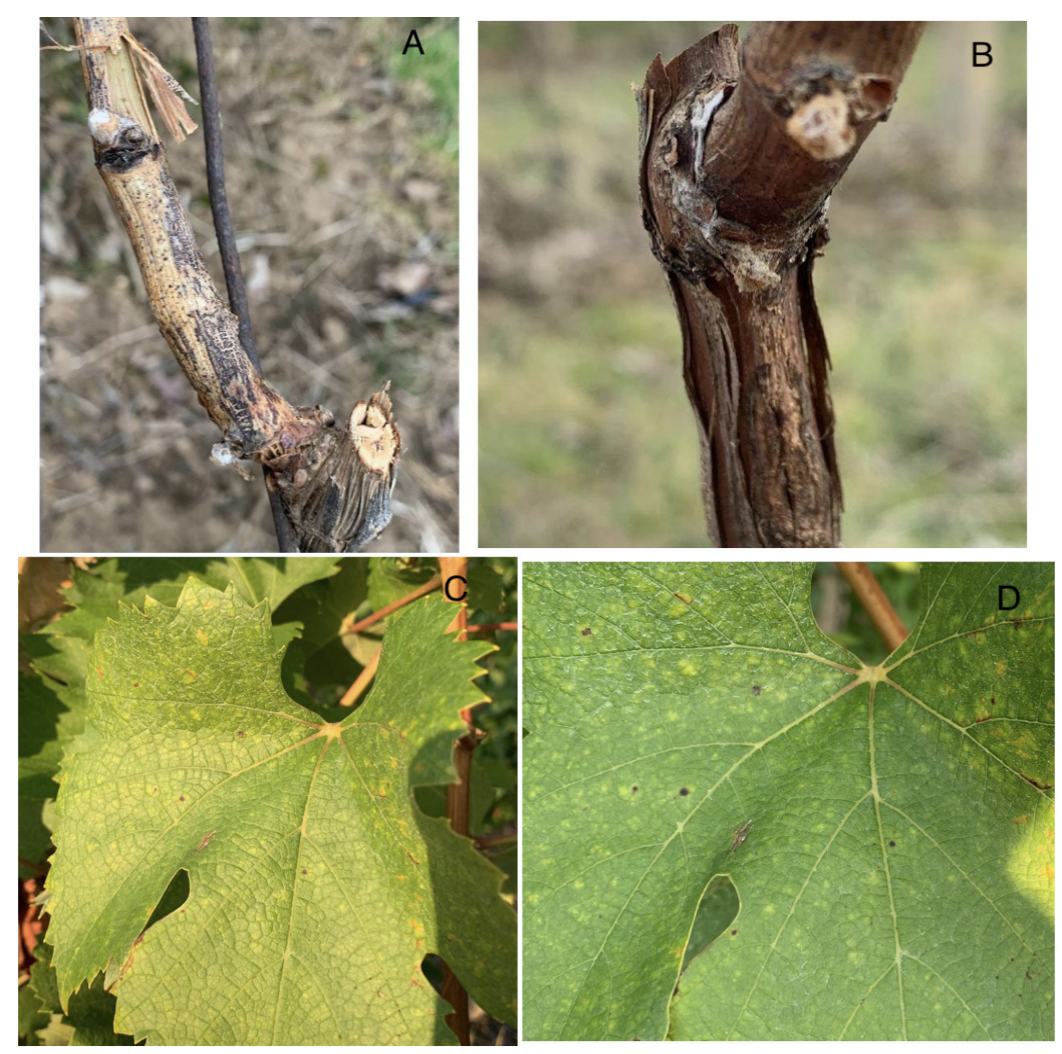

Figure 4. The excoriosis (Phomopsis cane or leaf spot) symptoms on canes (March 2020-first evaluation) A and B and on leaves (August 2020-last evaluation) C and D

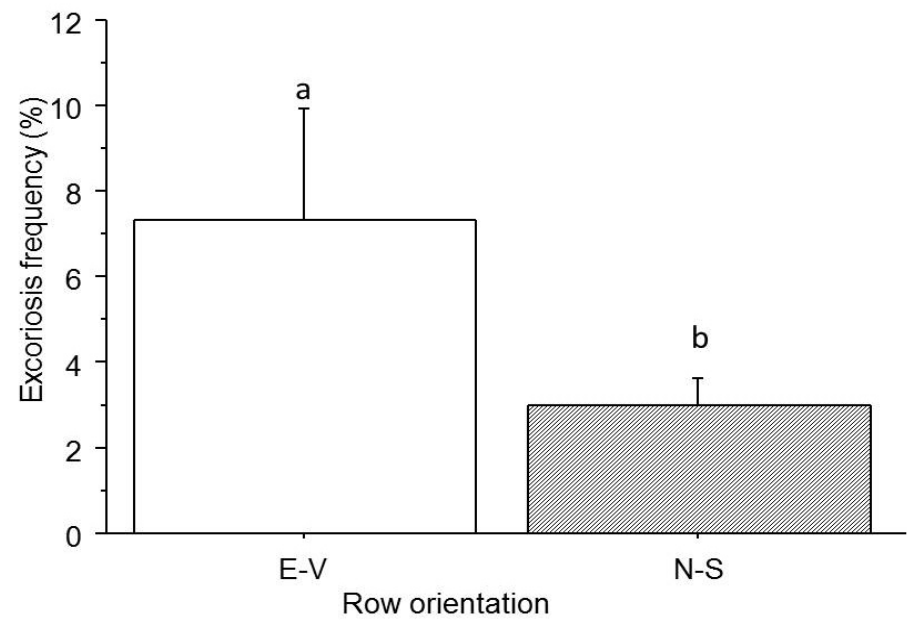

Figure 5. The excoriosis frequency according to the grapevine row orientation Different letters between cultivars denote significant differences (ANOVA), followed by a Fisher protected least significant difference test (PSLD) $\mathrm{P}<0.05$.

symptoms may be higher on the E-V orientation as it would be closer to the general circulations of the air masses. Indeed, as Figure 5 shows the presence of Phomopsis viticola attack was higher on the area oriented E-V $(7.33 \pm 2.60 \%$ for the E-V orientation vs. $3.00 \pm 0.62 \%$ for the $\mathrm{N}-\mathrm{S}$ orientation).

\section{Conclusion}

In the ecological conditions of spring and summer 2020, with higher temperature than the average in January, February, March and June, more rain than the average in February, March and June and less rain in January, April and May, we found 
frequency of the excoriosis in the range of $4 \%-12 \%$ at the beginning of the season. After the fungicide treatments, the attack frequency decreased up to $0 \%-7 \%$. Phomopsis viticola attack frequency was higher on the E-V oriented experimental plot as it would be closer to the general circulations of the air masses from this area. In the present research work, we show that in Aiud-Ciumbrud vineyards Phomopsis viticola attack was present and influenced by the microclimate conditions and also it was reduced by the fungicide treatments.

Acknowledgments. This work was supported by the Romanian Ministry of Agriculture and Rural Development, grants number ADER 7.5.3 and ADER 7.1.4.

\section{References}

1. Baumgartner K, Fujiyoshi PT, Travadon R, Castlebury LA, Rolshausen PE (2012). Characterization of Phomopsis species recovered from wood cankers in eastern North American vineyards. (Abstr.) Phytopathol. Mediterr. 51:420

2. Comșa M, Tomoiagă L, Cudur F, Cudur C, Cristea C (2012). Research on some pathogenic fungi involved in the biological decline of the grapevine at the Blaj Viticultural Centre. Lucrări Științifice, Universitatea de Științe Agricole Și Medicină Veterinară" Ion Ionescu de la Brad" Iași, Seria Horticultură, 55(2): 503-508.

3. Dissanayake AJ, Liu M, Zhang W, Chen Z, Udayanga D, Chukeatirote E, Li X-H, Yan,J-Y, Hyde KD (2015). Morphological and molecular characterisation of Diaporthe species associated with grapevine trunk disease in China. Fungal Biol. 119:283-294.

4. Erincik O, Madden LV, Ferree DC, Ellis MA (2001). Effect of growth stage on susceptibility of grape berry and rachis tissues to infection by Phomopsis viticola. Plant Dis. 85:517-520.

5. Farr DF, Rossman AY (2012). Fungal Databases, Systematic Mycology and Microbiology Laboratory, ARS, USDA. Retrieved August 10, 2020 from: http://nt.ars-grin.gov/ fungaldatabases/.

6. Gramaje D, Úrbez-Torres JR, Sosnowski MR (2018). Managing grapevine trunk diseases with respect to etiology and epidemiology: current strategies and future prospects. Plant Dis. 102(1):12-39.
7. Hewitt WB, Pearson RC (1988). Phomopsis cane and leaf spot in: Compendium of Grape Diseases (pp. 17-18). American Phytopathological Society, St. Paul, MN.

8. Mostert L, Groenewald JZ, Summerbell RC, Gams W, Crous PW (2006). Taxonomy and pathology of Togninia (Diaporthales) and its Phaeoacremonium anamorphs. Stud. Mycol. 54:1-113.

9. Moyo P, Allsopp E, Roets F, Mostert L, Halleen F (2014). Arthropods vector grapevine trunk disease pathogens. Phytopathology 104:1063-1069. Oprea M, Podosu A (2008). Grape dieback in Romania induced by pathogenic lignicoulus fungi. Lucrari Stiintifice USAMV Bucuresti, Seria B-LII-2008: 128-133.

10. Niekerk van JM, Calitz FJ, Halleen F, Fourie P H (2010). Temporal spore dispersal patterns of grapevine trunk pathogens in South Africa. Eur. J. Plant Pathol. 127:375390. https://doi.org/10.1007/s10658-010-9604-2

11. Phillips AJL (2000). Excoriose, cane blight and related diseases of grapevines: A taxonomic review of the pathogen. Phytopathol. Mediterr. 39:341- 356.

12. Pscheidt JW, Pearson RC (1989). Time of infection and control of Phomopsis fruit rot of grape. Plant Dis. 73:829833.

13. Tomoiaga LL, Chedea VS (2020). Grapevine Trunk Diseases management in vineyards from Central Transylvania. Bulletin of University of Agricultural Sciences and Veterinary Medicine Cluj-Napoca. Horticulture, 77(1): 117-121.

14. Urbez-Torres JR, Bruez E, Hurtado J, Gubler W D (2010). Effect of temperature on conidial germination of Botryosphaeriaceae species infecting grapevines. Plant Dis. 94:1476-1484.

15. Urbez-Torres JR, Peduto F, Smith RJ, Gubler WD (2013). Phomopsis dieback: A grapevine trunk disease caused by Phomopsis viticola in California. Plant Disease, 97:15711579.

16. https://www.meteoblue.com/ro/vreme/historyclimate/ weatherarchive/ciumbrud_românia_681432

17. https://www.cabi.org/isc/datasheet/40489 